\title{
Pawel Nowakowski
}

Uniwersytet Wrocławski

\section{Porównanie anarchistycznej etyki argumentacji Hoppego z demokratyczna isegoria grecka}

$24 / 2018$

Political Dialogues

DOI: http://dx.doi.org/10.12775/DP.2018.006

\begin{abstract}
:
The paper confronts the argumentation ethics developed by Hans-Hermann Hoppe, a libertarian and anarcho-capitalist thinker, with basic assumptions of the ancient democracy (originally called isegoria, that is, "an equal right to speak"), both of which are rooted in the phenomenon of discourse. Based on an analytical comparison the paper argues that possible similarities are superficial and deceptive. Indeed, despite some similarities prima facie, the theories in question have different nature and aims. The ethics of argumentation is a philosophical theory and as such has a different ambition than isegoria, which was a political system, even if it had some sound philosophical justification. The paper distinguishes three critical categories of analysis: argumentation, mutual recognition, and deliberation, none of which is found to possess a close meaning or function in both theories under investigation.
\end{abstract}

Keywords: Hans-Hermann Hoppe, libertarianism, democracy, isegoria, anarcho-capitalism, political theory, political philosophy, discourse ethics
Słowa kluczowe: Hans-Hermann Hoppe, libertarianizm, demokracja, isegoria, anarchokapitalizm, teoria polityki, filozofia polityki, etyka dyskursu

\section{Wprowadzenie}

Hans-Hermann Hoppe jest jednym $z$ niewielu filozofów sensu stricto wśród austro-libertarian, rozwijajacym libertariańska myśl polityczna przy wykorzystaniu aparatu metodologicznego i twierdzeń austriackiej szkoły w ekonomii. Krótko po emigracji do Stanów Zjednoczonych w połowie lat osiemdziesiatych dwudziestego wieku, motywowanej chęcia podjęcia współpracy z Murrayem N. Rothbardem, zaprezentował tzw. etykę argumentacji (argumentation ethics ${ }^{1}$ ), która stała się jedna $z$ kilku podstawowych propozycji uprawomocnienia libertarianizmu w warstwie metaetycznej ${ }^{2}$.

${ }^{1}$ Zob. H.-H. Hoppe, Teoria socjalizmu i kapitalizmu. Ekonomia, polityka i etyka, Wrocław 2015, rozdz. 7; Idem, Ekonomia i etyka własności prywatnej. Studia z zakresu ekonomii politycznej i filozofii, Warszawa 2011, cz. II.

${ }^{2} \mathrm{~W}$ niniejszym artykule termin "metaetyka” występuje w znaczeniu metaetyki szerszej, używanym przez Friedo Rickena, który wyróżnia etykę normatywną (poziom norm etycznych), metaetykę 
Szerszy rozgłos przyniosła mu książka Demokracja - bóg który zawiódł³, w której przedstawił krytykę demokratycznego ustroju politycznego i próbę wykazania wyższości klasycznej monarchii nad demokracją. Ponadto Hoppe opublikował liczne prace, w których zaproponował wiele oryginalnych, kontrowersyjnych $i$ inspirujacych tez $z$ zakresu filozofii politycznej, teorii polityki, prakseologii, ekonomii, epistemologii, historii i socjologii.

Problemem badawczym artykułu jest relacja między libertarianizmem Hoppego a podstawa teoretyczno-ustrojową starożytnej demokracji greckiej. Zdaje się bowiem, że w jego niezwykle radykalnej zarówno pod względem teoretycznym (dowodzenie tez z zakresu nauk społecznych poprzez dedukcję oparta na logice werbalnej), jak i politycznym (postulat uporządkowanej anarchii), etyce argumentacji można próbować dostrzec elementy demokratyczne, co zważywszy na wzmiankowane odrzucenie ustroju demokratycznego przez Hoppego, wydaje się spostrzeżeniem na wskroś paradoksalnym. Jednakże ten hipotetyczny związek pomiędzy anarchizmem Hoppego i demokracją ogranicza się do warstwy teoretycznej, a więc do ewentualnych podobieństw między etyką argumentacji a isegoria w starożytnej Grecji. Celem tego artykułu jest próba odpowiedzi na pytanie, czy, a jeśli tak, to na ile etyka argumentacji może być interpretowana $\mathrm{w}$ ten sposób. W toku poszukiwania odpowiedzi założenia Hoppego odnośnie do natury uprawnień zostały zestawione z grecka teoria demokratyczna. W artykule użyto zatem metody porównaw-

szersza (metoda uzasadnienia norm) i metaetykę węższa (język etyki). Zob. F. Ricken, Etyka ogólna, Kęty 2001.

${ }^{3}$ Zob. H.-H. Hoppe, Demokracja - bóg, który zawiódt. Ekonomia i polityka demokracji, monarchii i ładu naturalnego, Warszawa 2006. czej, ale także hermeneutycznej, zaś tło interpretacyjne stanowi głównie fenomenologiczna refleksja na temat polityki przedstawiona w wykładach Klausa Helda zebranych w pracy Fenomenologia świata politycznego ${ }^{4}$, a pomocniczo także uwagi innych autorów.

Tekst ma charakter analityczny, a rezultatem badań jest głębsze zrozumienie etyki argumentacji poprzez hermeneutyczne odniesienie jej głównych założeń do greckiej tradycji demokratycznej. Badania ogniskuja się wokół siatki pojęć wyznaczonej przez kluczowe pojęcie argumentacji, a także charakterystyczny dla klasycznej filozofii polityki podział na doksa (gr. mniemanie) i episteme (gr. wiedza). Do tej pory przedstawiony problem badawczy nie był poruszany w literaturze. Co więcej, studia odnoszace libertarianizm do innych kierunków w filozofii i teorii polityki należa do rzadkości, stąd kolejnym rezultatem artykułu jest poszerzenie horyzontu myślowego w refleksji nad tym nadal młodym nurtem politycznym.

\section{Założenia etyki argumentacji ${ }^{5}$}

Teoria argumentacyjna Hoppego czerpie $z$ etyki dyskursu uprawianej przez Karla-Ottona Apla i Jürgena Habermasa nota bene promotora doktoratu Hoppego. Etyka argumentacji nie ma wnosić niczego nowego do treści podstawowych zasad etycznych libertarianizmu: autowłasności, pierwotnego zawłaszczenia i zasady nieagresji - jej zadaniem jest

${ }_{4}$ Zob. K. Held, Fenomenologia świata politycznego, Warszawa 2003.

${ }^{5}$ Wyczerpujace omówienie, a tym bardziej krytyczna analiza etyki argumentacji nie jest celem tego artykułu. Zainteresowany czytelnik znajdzie więcej na ten temat np. w artykule Norberta Slenzoka i cytowanej tam literaturze. Zob. N. Slenzok, Od transcendentalnej pragmatyki jezyka do libertariańskiej etyki argumentacyjnej, „Eryda” 1(3)/2016. 
ich ostateczne uzasadnienie (Letztbegründung) Stąd, podczas gdy konkluzje polityczne wywiedzione $z$ etyki dyskursu głównego nurtu mogą mieć charakter socjaldemokratyczny, etyka argumentacji w wersji Hoppego prowadzi nieuchronnie do anarchokapitalizmu, który on sam preferuje nazywać ładem naturalnym ${ }^{6}$.

W rzeczywistości Hoppe korzysta $\mathrm{w}$ nie mniejszym zakresie $\mathrm{z}$ prakseologii Ludwiga von Misesa, niż z etyki dyskursu, radykalizując oba paradygmaty i łaczac je w etyke argumentacji. Hoppe rozpoczyna swoje badania od refleksji nad Misesowska kategoria działania, uwypuklając aksjomatyczny i aprioryczny charakter ludzkiego działania poprzez wykorzystanie zasady niesprzeczności performatywnej ${ }^{7}$. Przekonuje zatem, że nie można zaprzeczyć, że się działa nie wykonując działania ${ }^{8}$. Co niezwykle istotne dla jego kolejnych wniosków, Hoppe stawia tezę, że prakseologia jest podstawa epistemologii (wskazujacc jednocześnie, że Mises miał tego świadomość, jednak nie rozwiną tego watku w swoich studiach ${ }^{9}$ ).

W następnym kroku libertariański myśliciel rozwija twierdzenie o prakseologicznych uwarunkowaniach epistemologii, dodajac do aksjomatu działania $\mathrm{i}$ dostrzeganych $\mathrm{w}$ nim implikacji filozoficznych drugi aksjomat $\mathrm{w}$ postaci sformułowanego przez Apla „a priori argumentacji”, tj. „ludzie sa zdolni do argumentacji, a zatem znaja znaczenie prawdy i ważności” ${ }^{10}$. Ponadto:

${ }^{6}$ H.-H. Hoppe, Demokracja..., s. 27.

7 Zob. szerzej B. Sierocka, Krytyka i dyskurs. $O$ transcendentalno-pragmatycznym uprawomocnieniu krytyki filozoficznej, Kraków 2003.

${ }^{8}$ Zob. np. H.-H. Hoppe, Teoria..., s. 121.

${ }_{9}^{9}$ Zob. Idem, Ekonomia..., s. 290-291.

${ }^{10}$ Ibidem, s. 291 [tłumaczenie zmienione: słowo 'validity' oddano jako „ważność” (w rozumieniu bliskiemu zasadności) zamiast „słuszność”]; zob. też ibidem, passim.
„Prawomocność [tego - P.N.] aksjomatu, podobnie jak aksjomatu działania, jest bezsporna. Nie można zaprzeczyć, że można argumentować, ponieważ samo zaprzeczenie stanowiłoby argumentację (...). Nie można argumentować, że nie można argumentować. Nie można też podważać wiedzy o tym, co to znaczy twierdzić, że coś jest prawdziwe czy ważne, nie zakładając implicite, że negacja tego twierdzenia jest prawdziwa" ${ }^{11}$.

W zwiazku z tym, argumentacja jest zawsze działaniem, a ponadto wszystkie tezy musza być sformułowane na drodze argumentacji, dlatego też, twierdzi Hoppe: „[M]usza istnieć intersubiektywne, zrozumiałe normy - dokładnie te, które czynią jakieś działanie argumentacja majace specjalny status poznawczy jako praktyczne warunki wstepne obiektywności i prawdy"12. Zdaniem libertariańskiego filozofa, taka norma jest własność swojego ciała, za pomoca którego można wykonywać działania, w tym również argumentować i komunikować się. Co ważne, Hoppe podkreśla pokojowy charakter dyskursu argumentacyjnego, w ramach którego, nawet nie zgadzając się co do meritum, dyskutanci moga nadal zgodzić się co do występowania między nimi braku zgody na dany temat ${ }^{13}$.

$\mathrm{Z}$ perspektywy tego artykułu węzłowymi elementami etyki argumentacji sa:

- argumentacja - rozumiana jako działanie manifestujace roszczenie ważnościowe, tj. stwierdzenia, któremu podmiot przypisuje prawomocność;

- wzajemne uznanie równych praw przez osoby uczestniczące w sytu-

11 Ibidem, s. 291-292.

${ }_{12}$ H.-H. Hoppe, Ekonomia..., s. 327 [tłumaczenie zmienione: słowo 'meaningful' oddano jako „zrozumiałe”, zamiast „znaczace”].

13 Ibidem, s. 229-330. 
acji argumentacyjnej, gdyż nolens volens każda osoba, która bierze udział w dyskusji, musi - w sensie ontologicznym - zakładać, że druga strona dyskusji ma takie same uprawnienia;

- deliberacja - będaca sposobem osiągnięcia porozumienia (konsensusu) w kwestiach normatywnych odnoszących się do relacji międzyludzkich w społeczeństwie czy, ujmujac to inaczej, jedynym uprawnionym źródłem prawa pozytywnego.

\section{Etyka argumentacji a grecka teoria demokracji - podobieństwa prima facie}

Rdzeniem powstającego w starożytności demokratycznego systemu politycznego było nadanie sobie nawzajem przez Greków statusu obywateli uprawnionych do wypowiadania sie na tematy dotyczace wspólnoty ${ }^{14}$. Jak pisał Isokrates w drugiej połowie IV w. p. n. e.:

„[S]koro rozwinęliśmy w sobie zdolność przekonywania siebie nawzajem i uświadamiania samym sobie, czego dotyczą nasze pragnienia, nie tylko uwolniliśmy się od życia w dzikości, ale i łącząc się w społeczności, założyliśmy poleis, ustanowiliśmy dla siebie prawa, wynaleźliśmy rzemiosła. Niemal wszystko, co stworzyliśmy, dokonało się za sprawą logosu [rozsądnej mowy ${ }^{15}$ - P.N.]. On bowiem ustanowił prawa decydujące, co jest sprawiedliwe, a co niesprawiedliwe, co piękne, a co brzydkie (...). Z pomocą logosu dyskutujemy o rzeczach spornych i zastana-

${ }^{14}$ K. Held, op. cit., s. 28

15 Tak w tym kontekście każe rozumieć logos cytujacy Isokratesa John Kenyon Davies. J. K. Davies, Demokracja w Grecji klasycznej, Warszawa 2003, s. 194. wiamy się nad nieznanymi, albowiem argumenty, którymi przekonujemy innych $\mathrm{w}$ rozmowie, są tymi samymi, których używamy w myśli” ${ }^{16}$.

Możemy tu zauważyć pewne podobieństwo między prowadząca do anarchizmu etyka argumentacji a grecka koncepcja demokracji. Punktem wspólnym jest logos, który tutaj wydaje się oznaczać „mowę”, „rozum” i regulująca zasadę metafizyczną ${ }^{17}$. Zarówno argumentacja, jak i logos maja wymiar wolicjonalny/ subiektywny - udział w dyskusji jest efektem działania podmiotu, jak również obiektywny - logos jest racjonalnościa, rozumem i pierwotna zasada, która umożliwia odkrywanie sprawiedliwości i piękna oraz organizację życia między ludźmi w ogóle, zaś a priori argumentacji, w połaczeniu $z$ a priori działania, jest warunkiem sine qua non zdobywania wiedzy na temat norm.

Jednak najbardziej znamienne wydaje się, że - jak wskazuje Held ${ }^{18}$ - początkowo Grecy nie nazywali swojego ustroju demokratia, lecz isegoria ${ }^{19}$, co tłumaczy się jako „równość publicznego mówienia", która przysługiwała obywatelom, tj. członkom demosu. Isegoria nawiązuje do słowa agoreuein - „mówić publicznie”, które zawiera w sobie rzeczownik agora,

16 Cyt. za: ibidem, s. 195.

17 M. Osmański, Logos, http://www.ptta.pl/ pef/pdf/1/logos.pdf.

18 K. Held, op. cit., s. 28.

19 Zob. też M.-H. Hansen, Was Athens a Democracy? Popular Rule, Liberty and Equality in Ancient and Modern Political Thought, Copenhagen 1989, s. 23. Przedrostek iso- wskazujacy na równość używany był w Atenach także w odniesieniu do innych politycznie istotnych cech obywateli, np. isonomia (równość praw politycznych), isotymia (równość szacunku), isogonia (równość urodzenia) czy isokratia (równość władzy). Ibidem, s. 21; $\mathrm{K}$. Dziubka, Obywatelskość jako virtù podmiotu demokracji, Wrocław 2008, s. 60. 
czyli „rynek”20. Na tej podstawie widzimy więc, że to isegoria była punktem odniesienia w przytoczonej wypowiedzi Isokratesa, stąd taki nacisk nie na ludowładztwo, ale właśnie na mowę i komunikację. Ponieważ funkcja isegorii polegała przede wszystkim na umożliwieniu konsensusu w zakresie decyzji dotyczacych polis, zabieraniu głosu na agorze miała towarzyszyć powaga, odpowiedzialność i wzajemny szacunek między obywatelami ${ }^{21}$, co tłumaczy podkreślenie przez Helda, że kiedy Arystoteles pisał o logos w kontekście polityczno-ustrojowym, nie chodziło mu o samo mówienie, lecz raczej o „zdawanie sprawy" 22 .

$\mathrm{Na}$ kardynalne znaczenie mowy dla starożytnych Greków zwraca uwagę również m.in. Hannah Arendt ${ }^{23}$, choć jej analizę warto przytoczyć głównie $z$ powodu sugestywnego w kontekście tego artykułu podkreślenia relacji między mowa a działaniem - tak charakterystycznego dla myśli Hoppego. Arendt wskazuje na jakościowa równoważność mowy i działania u Greków, i powiada, że uważali oni, iż „działanie najbardziej polityczne, o ile pozostaje poza sfera przemocy, $\mathrm{w}$ istocie odbywa się w słowach" oraz że: „znajdowanie właściwych słów we właściwym momencie (...) jest działanie$\mathrm{m}$ "24. Jak dodaje w opublikowanej po raz pierwszy w 1958 roku Kondycji ludzkiej, $\mathrm{w}$ greckiej tradycji politycznej rola działania ustępowała $z$ czasem mowie. Przekonana o już tylko historycznym znaczeniu powiąania mowy $z$ działaniem pisze Arendt: „Ostatni ślad tego starożytnego powiązania między mową i działaniem, które nie jest już obecne $\mathrm{w}$ naszym po-

${ }^{20}$ K. Held, op. cit., s. 28.

${ }^{21}$ K. Dziubka, op. cit., s. 60.

${ }^{22}$ K. Held, op. cit., s. 28.

${ }^{23} \mathrm{H}$. Arendt, Kondycja ludzka, Warszawa 2010, s. 44-47.

${ }^{24}$ Ibidem, s. 45. jęciu mowy jako wyrażania słowami myśli znaleźć można w rozpowszechnionym powiedzeniu Cycerona ratio et oratio" 25 .

Pojawili się jednak współcześni filozofowie, którzy odnowili ów związek między mowa i działaniem ${ }^{26}$, co w przypadku Hoppego miało miejsce dokładnie trzy dekady po opublikowaniu pracy Arendt. Ponadto wykorzystujac Misesowska prakseologie i dowodząc, że argumentacja jest działaniem, Hoppe identyfikuje ten specyficzny rodzaj mowy jako najważniejszy element filozofii politycznej i etyki politycznej.

\section{Dyskusja}

Powyższa uwaga wydaje się być kluczowa, bowiem etyka argumentacji jest nie tylko oryginalna próbą uzasadnienia libertariańskiej filozofii politycznej, lecz wpisuje się także w określony głos w mającej poczatek w starożytnej Grecji debacie na temat życia politycznego. Hoppe odnosi się do argumentacji jako zjawiska powszechnego, empirycznego, właściwego ludziom i stara się dowieść argumentacyjno-prakseologicznie zapośredniczonej, w sensie logicznym i praktycznym, nieuchronności nie tylko biernego, ale bezsprzecznie aktywnego uczestnictwa człowieka w obiektywnym porzadku episteme (gr. wiedzy, nauki), aby wybrzmiało, że postępując wbrew etyce argumentacji człowiek zaprzecza sam sobie i jest niewiarygodny wobec samego siebie. W ten sposób, podązając za Aplem i Habermasem, Hoppe proponuje osadzona na gruncie wiedzy obiektywnej i apodyktycznie prawdziwej etykę polityczna, która jest znacznie bardziej radykalna od greckiej teorii demokratycznej. Albowiem tego rodzaju teoretyczne zdo-

\footnotetext{
25 Loc. cit.

${ }^{26}$ Patrz Slenzok, op. cit.
} 
minowanie doksa (gr. mniemanie) przez episteme nie nastapiło nawet u Heraklita, który krytykował mieszkańców Hellady za ugrzęźnięcie w swoich partykularnych, „naturalnych” światopoglądach i brak jakiegokolwiek otwarcia na to, co wspólne, na jeden świat ${ }^{27}$.

Held krytykuje Heraklita za nierealność jego postulatów w obliczu naturalnej obecności doksa w życiu ludzkim i opisuje, że ostatecznie „zmysł polityczny" u Greków, a w efekcie ustrój demokratyczny i polis wykształciły się poprzez powstanie innego rodzaju wspólnotowości, która wcale nie zrywała $z$ doksa, lecz znajdowała w nim swoje źródło przezwyciężajac jednakowoż podział na to, co naturalne i filozoficzne. Osiagnięto to dzięki nadaniu sobie nawzajem przez obywateli greckich prawa do zachowania swoich własnych horyzontów myślowych zbudowanych na mniemaniach oraz do publicznego prezentowania swoich mniemań dotyczących spraw wspólnoty przy jednoczesnym założeniu, że obywatele będą w stanie refleksyjnie rozważyć polady innych bez wymogu porzucania własnych horyzontów wyjściowych na rzecz otwarcia się na jeden wspólny świat spod znaku episteme ${ }^{28}$. Nawiasem mówiąc, założenie o możliwości wzajemnego otwarcia się na opinie, poglądy, mniemania przedstawiane przez „zdajacych sprawe” obywateli wydaje się w tak zorganizowanym ustroju polis naturalne, ponieważ usankcjonowanie partykularnych mniemań bez założenia, że istnieje możliwość argumentowania i zrozumienia się, znosiłaby sens prawa do publicznego mówienia, czyli samej isegorii.

Ten poziom analizy, wskazujacy na epistemiczny ${ }^{29}$ wymiar etyki argumenta-

${ }^{27}$ Zob. K. Held, op. cit., s. 20-25; K. Dziubka, op. cit., s. 28-29.

${ }^{28}$ K. Held, op. cit., s. 20-29, 32-33.

${ }^{29}$ Nie należy mylić $z$ koncepcja demokracji cji w przeciwieństwie do doksokrytycznego charakteru greckiej demokracji, sprawia, że dostrzegane na pierwszy rzut oka podobieństwa między nimi są powierzchowne czy nawet pozorne. Etyka argumentacji jest libertariańską teoria filozoficzna, nie zaś doktryna polityczna i jako taka nie jest nastawiona na wdrożenie jej do praktyki politycznej. Taka funkcję ma dopiero anarchokapitalizm, wspierany m.in. przez metaetyke Hoppego na gruncie etycznym ${ }^{30}$. Celem etyki argumentacji jest pokazanie, dlaczego libertariański anarchokapitalizm jest jedynym dajacym się racjonalnie uprawomocnić systemem politycznym. Przy czym warto zwrócić uwage na fakt, że etyka argumentacji, mimo swojego esencjalizmu, dopuszcza znacznie szerszy zakres działań niż dozwolony był przez grecka demokrację, mianowicie dozwolone sa wszelkie czyny wobec swojej osoby i własności, a także wszelkie dobrowolne relacje $z$ innymi. Natomiast teoria demokracji greckiej jest koncepcja polityczno-ustrojowa, która posługując się kryterium szczegółowości - bliższa jest raczej ideologii niż doktrynie politycznej, zaś jej celem nie była obiektywna wiedza o świecie politycznym, lecz raczej zabezpieczenie interesów obywateli greckich, posiadajacych i ceniących swoje własne poglądy i horyzonty myślowe - na co dużą uwage zwraca Held.

Posługujac się jako tłem interpretacyjnym węzłowymi kategoriami wskazanymi w sekcji o założeniach etyki

epistemicznej, chociaż ma ona wyraźne związi z etyka dyskursu. Zob. K. Dziubka, Demokracja epistemiczna, [w:] J. Juchnowski i R. Wiszniowski (red.), Studia nad współczesnymi systemami politycznymi. Podmioty i procesy demokratyczne. Ksiega dedykowana Profesorowi Andrzejowi Antoszew skiemu, Toruń 2014, s. 110-117.

${ }^{30}$ Zob. P. Nowakowski, Anarchokapitalizm ideologia polityczna, doktryna polityczno-prawna czy nurt filozoficzno-polityczny?, „Societas et Ius”, 5/2016, s. 31-46. 
argumentacji, tj. 1) argumentacja, 2) wzajemnym uzdaniem i 3) deliberacja, można owszem zgodzić się, że każde $z$ tych pojęć ma fundamentalne znaczenie również dla greckiej teorii demokracji czy isegorii, niemniej jednak przy próbie ekstrapolacji wyróżnionych kategorii etyki argumentacji na grecką demokrację jest jasne, że rozumienie i funkcje tych kategorii sa diametralnie różne w obu konstrukcjach.

Podczas gdy isegoria odnosi się do spraw dotyczacych wspólnoty, spraw publicznych, argumentacja jest niewrażliwa na antyczny podział na sferę publiczna i prywatna, i odnosi się do wszelkich przypadków dyskursywnych. Co więcej, mimo wskazanych przy okazji analizy fragmentu dzieła Isokratesa podobieństw między argumentacja a logosem, założenia leżace u podstaw publicznego mówienia i argumentacji sa skrajnie różne. Argumentacja zakłada roszczenia ważnościowe, czyli pretensje do prawdziwości (obiektywnej obowiązywalności) wypowiadanych stwierdzeń, natomiast isegoria zdaje się zakładać coś wprost przeciwnego: że obywatel mówiący publicznie dzieli się nie sądem, który uważa za obiektywna wiedzę, ale własnym mniemaniem mającym źródło w jego partykularnym oglądzie świata i doświadczeniach, z czego domyślnie zdaje sobie sprawę (ponieważ doksa wywodzi się od dokei moi, czyli „wydaje mi się” czy jak dookreśla to Held: „tak mi się wprawdzie wydaje, lecz nie mogę tego twierdzić $z$ cała moca" $\left.{ }^{31}\right)$. W efekcie, w przypadku argumentowania ważny jest analogiczny wniosek, jaki sformułowano w odniesieniu do relacji etyki argumentacji i isegorii jako takich: w Grecji argumentowanie miało funkcję polityczno-ustrojowa, u Hoppego jest zaś narzędziem filozoficzno-naukowym.
Tak jak w przypadku argumentacji, wzajemne uznanie ma szerszy wymiar $\mathrm{w}$ ramach etyki argumentacji niż w isegorii, ponieważ dotyczy wszystkich argumentujacych, a nie tylko obywateli. Ponadto wzajemne uznanie jest w teorii Hoppego koniecznym założeniem rozumu, i stąd też obejmuje wszystkich, natomiast $\mathrm{w}$ greckiej demokracji miało ono źródło w woli politycznej, a więc było czymś, co może mieć miejsce, lecz nie musi. Zdecydowało o tym nadanie sobie przez obywateli statusu podmiotów uprawnionych do publicznego mówieni o sprawach polis.

$\mathrm{Z}$ zagadnieniami wzajemnego uznania i argumentacji, wiąża się odmienne w obu przypadkach kryteria posiadania pełni uprawnień. Hoppe uważa, że wszyscy zdolni do argumentacji - tak jak ja definiuje - posiadaja równe i pełne uprawnienia, co nota bene jest zgodne $z$ przyjęta $w$ libertarianizmie zasada uniwersalizacji w etyce. Jak wiadomo, inaczej było w przypadku greckiej demokracji, gdzie pełnia uprawnień przysługiwała tylko demosowi, tj. obywatelom, mimo że antropologia grecka również zasadzała się - jak wskazuje Held za Arystotelesem - na obrazie człowieka jako istoty mówiącej (zoon logon echon) i właśnie dlatego stworzonej do roli obywatela $\mathrm{w}$ polis ${ }^{32}$. W tym aspekcie teoria Hoppego jest znacznie bardziej inkluzywna i egalitarna.

W kontekście porównawczym najmniej jednoznaczna spośród trzech wzmiankowanych kategorii jest deliberacja. Na pierwszy rzut oka wydaje się ona być punktem wspólnym teorii Hoppego i teorii demokratycznej. Formalnie tak rzeczywiście jest, jednak w istocie deliberacja jest w myśli Hoppego elementem pozornym, którego funkcją nie jest 
swoiste „ustalanie” praw i norm, lecz dowiedzenie, że pewne normy musza być zakładane jeszcze zanim $z$ deliberacji wykluje się jakieś porozumienie odnośnie do norm oraz - co najistotniejsze - że owe normy warunkujace deliberację nie moga być w jej następstwie zakwestionowane, gdyż byłoby to wewnętrznie sprzeczne ${ }^{33}$. Tego rodzaju podejście jest $z$ gruntu obce greckiej teorii demokratycznej, w ramach której nie istnieja tak daleko idacce obostrzenia i rzeczywiste pole do debaty jest realne, a nie jak u Hoppego, formalne lub ograniczone do ustalaniu warunków dobrowolnych relacji czy perswazji.

\section{Bibliografia}

Arendt Hannah, Kondycja ludzka, tłum. A. Łagodzka, Warszawa 2010.

Davies John Kenyon, Demokracja w Grecji klasycznej, tłum. G. Muszyński, Warszawa 2003.

Dziubka Kazimierz, Demokracja epistemiczna, [w:] J. Juchnowski i R. Wiszniowski (red.), Studia nad współczesnymi systemami politycznymi. Podmioty i procesy demokratyczne. Ksiega dedykowana Profesorowi Andrzejowi Antoszewskiemu, Toruń 2014, s. 110-117.

Dziubka Kazimierz, Obywatelskość jako virtù podmiotu demokracji, Wrocław 2008.

Hansen Mogens Herman, Was Athens a Democracy? Popular Rule, Liberty and Equality in Ancient and Modern Political Thought, Copenhagen 1989,

Held Klaus, Fenomenologia świata politycznego, tłum. A. Gniazdowski, Warszawa 2003.

${ }^{33}$ H.-H. Hoppe, Ekonomia..., s. 327-328, 419.
Hoppe Hans-Hermann, Demokracja bóg, który zawiódł. Ekonomia i polityka demokracji, monarchii i ładu naturalnego, tłum. W. Falkowski, J. Jabłecki, Warszawa 2006.

Hoppe Hans-Hermann, Ekonomia i etyka własności prywatnej. Studia z zakresu ekonomii politycznej ifilozofii, tłum. K. Nowacki, Warszawa 2011.

Hoppe Hans-Hermann, Teoria socjalizmu i kapitalizmu. Ekonomia, polityka i etyka, tłum. P. Nowakowski, Wrocław 2015.

Nowakowski Paweł, Anarchokapitalizm ideologia polityczna, doktryna polityczno-prawna czy nurt filozoficzno-polityczny?, „Societas et Ius”, 5/2016, s. 31-46.

Osmański Marek, Logos, http://www. ptta.pl/pef/pdf/1/logos.pdf.

Ricken Friedo, Etyka ogólna, tłum. P. Domański, Kęty 2001.

Sierocka Beata, Krytykaidyskurs. Otranscendentalno-pragmatycznym uprawomocnieniu krytyki filozoficznej, Kraków 2003.

Slenzok Norbert, Od transcendentalnej pragmatyki języka do libertariańskiej etyki argumentacyjnej, „Eryda” 1(3)/2016. 